\title{
Specific Interventions to Prevent Stunting in Children Under 2 Years after the Natural Disaster
}

\author{
Fahmi Hafid ${ }^{1,2 *}$, Taqwin Taqwin ${ }^{1,2}$, Linda Linda ${ }^{1}$, Nasrul Nasrul $^{1}$, Kadar Ramadhan $^{1}$, Bohari Bohari $^{3}$ \\ ${ }^{1}$ Nutrition Department, Poltekkes Kemenkes Palu, City of Palu, Indonesia; ${ }^{2}$ Stunting, CBTS and Disaster Health Study Centre, \\ City of Palu, Indonesia; ${ }^{3}$ Nutrition Department, Faculty of Medicine, Universitas Sultan Ageng Tirtayasa, Serang, Indonesia
}

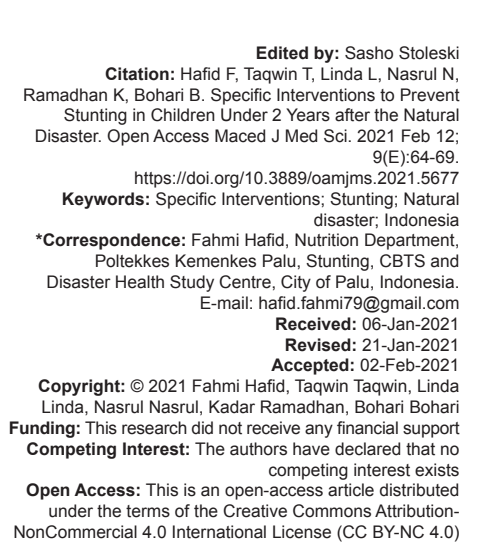

\section{Introduction}

Nearly three decades of research support a strong relationship between the complicated biological processes that can occur during the first 1000 days of life and the resulting multiple burdens of malnutrition, including stunting [1], [2], [3]. Specific intervention is an action or activity that is specifically directed at the first 1000 days life children. In general, these activities are carried out by the health sector, such as immunization, supplementary feeding for pregnant women and infants, monitoring the growth of infants, supplementation of iron-folate tablets for pregnant women, promotion of exclusive breastfeeding, and supplementary feeding of breast milk. The specific intervention is short term, and it is possible to record the results in a relatively short time. Different development activities outside the health sector are sensitive interventions. However, if planned specifically and integrated with specific activities, the impact is sensitive to the safety of the first 1000 days of life's growth and development process [4].

The Republic of Indonesia's Ministry of Health Basic Health Research reported that the national prevalence of child stunting was $37.2 \%$ in 2013 and decreased to $30.2 \%$ in 2018 [5], [6]. The problem of stunting still needs to be controlled, despite the decline [7]. Sumiaty et al. study showed that maternal height of $<150 \mathrm{~cm}$, birth spacing of $<3$ years, and lack of prenatal care were risk factors for stunting [8]. Ethiopian research shows that risk factors for stunting include maternal age $>30$ years, mothers without formal education, mothers who work every day, mothers who do not perform PNC, and mothers who are ill during pregnancy [9]. Research in Bhutan shows that the risk factors for stunting in children 6-23 months are; the antenatal care (ANC) factor is $<3$ times, doctors, nurses, and midwives and mothers who are $<18$ years old do not perform ANC [10]. Prevention efforts can, therefore, be carried out by streamlining existing health programs, such as prenatal care, classes for pregnant women, supplementation with iron and calcium, and supplementary feeding for pregnant women [11]. In particular, through breastfeeding behavior improvement programs, a study also suggested long breastfeeding [12]. The government allocated national priority projects to reduce stunting in 2018 , one of which is to improve maternal and reproductive health services [13].

A major earthquake with a current magnitude of 7.5 occurred on the island of Sulawesi, Indonesia, on September 28, 2018. This earthquake caused extensive 
tsunami and liquefaction [14], [15], [16]. The impact of the earthquake was felt in Palu City, which is the location of this research. In catastrophic situations such as earthquakes, infants and young children have been identified as the most nutritionally vulnerable groups. In the early years of life, malnutrition and poor feeding practices may adversely affect the growth, cognitive, physical, and social development of children. The results of previous studies show that there are statistically significant differences in wasting, underweight, and stunting before and after the earthquake in various regions [17], [18], [19]. Study aims to analyze specific interventions for preventing stunting in children under 2 years of age in post-natural disaster areas.

\section{Materials and Methods}

This type of quantitative analytic research with a cross-sectional design conducted in Palu City from October until November 2020. The population in this study were mothers and children under 2 years in Palu City. Sampling using consecutive sampling technique with a total of 384 samples. Measuring instruments are in the form of tested questionnaires and length board measuring body length measuring instruments. The data used in this study are primary data and secondary data. Primary data are in the form of interventions that have been carried out on pregnant women, women giving birth, and children 0-23 months. Data analysis of specific nutrition interventions for mothers and children under 5 years of age was univariate using a frequency distribution, height using the $\mathrm{Z}$ score table according to the Ministry of Health of the Republic of Indonesia, and bivariate analysis using the Chi-square test. This study uses several strategies to maintain data quality standards. The first control begins with selecting field workers. The selected field workers are those who have the hard ability to collect data in the field, both quantitative data and qualitative data. Before going to the field, they were given training to equalize perceptions and how to measure/collect data in the field. The next step is to standardize research instruments, body length measuring instruments, and questionnaires. Standardization is carried out by conducting field trials in accordance with the conditions of the research location, the questionnaire trial is carried out in the work area of the Mamboro Community Health Center.

\section{Results}

This study involved 384 children under 2 years old who were paired with their mothers. Table 1 show that mothers of children under 2 years aged 20-35 years were $81.77 \%$. The age of children $0-11$ months is $50.52 \%$. Most of the respondents were male at $54.69 \%$. The prevalence of stunting in children under 2 years of age in Palu was $37.24 \%$.

Table 2 show that there are 13 behaviors in the specific intervention group in efforts to prevent stunting in children under 2 years that were identified in this study. A 2-year-old child and his mother were victims of the earthquake, tsunami, and liquefaction in Palu City on September 28, 2018.

Table 1: Respondents characteristics in specific interventions to prevent stunting in children under 2 years after the natural disaster

\begin{tabular}{lll}
\hline Variable & Frequency $(384)$ & Percentage (100\%) \\
\hline Mother age & 16 & \\
$\quad<20$ years & 314 & 4.17 \\
20-35 years & 54 & 81.77 \\
$\quad>35$ years & & 14.06 \\
Child age & 194 & \\
$\quad 0-11$ months & 190 & 50.52 \\
$\quad$ 12-23 months & & 49.48 \\
Child sex & 210 & \\
$\quad$ Boys & 174 & 54.69 \\
$\quad$ Girls & & 45.31 \\
Nutritional status children under 2 years & 143 & 37.24 \\
$\quad$ Stunting & 241 & 62.76 \\
$\quad$ Normal & & \\
\hline
\end{tabular}

The results showed that there was a correlation between increasing age and the prevalence of stunting, namely the increasing age of children under five, the higher the prevalence of stunting. Table 3 show that in the $0-11$ months age group, the prevalence of stunting was $24.23 \%$, while in the $12-23$ months group, the prevalence of stunting was $50.53 \%$. This difference was statistically significant $(p=0.000)$. The only specific intervention behavior in preventing stunting that was statistically significant was breastfeeding for up to 2 years $(p=0.025)$. In the group of mothers who consistently gave breast milk for up to 2 years, the prevalence of stunting was only $39.18 \%$. The behavior of other specific interventions in preventing stunting was not statistically significant.

\section{Discussion}

Children under 2 and his mother were victims of the earthquake, tsunami, and liquefaction in the context of crisis and post-natural disasters, specific interventions implemented in Palu City for the first 1000 days of life for stunting prevention, in Palu Central Sulawesi showed a $37.24 \%$ prevalence of stunting in children under 2 years. The only specific intervention behavior that was statistically significant in preventing stunting was breastfeeding for up to 2 years.

The length and weight of breastfed infants during the first 2 years in developing countries are highly affected by the respective anthropometric parameters at birth. Gambia and Zimbabwe studies indicate that only breastfed infants with birth length and weight 
Table 2: Specific interventions to prevent stunting in children under 2 years after the natural disaster

\begin{tabular}{|c|c|c|}
\hline Variable & $\begin{array}{l}\text { Frequency } \\
(384)\end{array}$ & $\begin{array}{l}\text { Percentage } \\
(100 \%)\end{array}$ \\
\hline \multicolumn{3}{|c|}{ Breastfeeding until 2 years of age } \\
\hline No & 42 & 10.94 \\
\hline Yes & 342 & 89.06 \\
\hline \multicolumn{3}{|c|}{ Giving biscuit to pregnant women } \\
\hline No & 18 & 4.69 \\
\hline Yes & 366 & 95.31 \\
\hline \multicolumn{3}{|c|}{ Provision of iron supplement tablets to pregnant women } \\
\hline No & 1 & 0.26 \\
\hline Yes & 383 & 99.74 \\
\hline \multicolumn{3}{|c|}{ Calcium supplementation to pregnant women } \\
\hline No & 5 & 1.30 \\
\hline Yes & 379 & 98.70 \\
\hline \multicolumn{3}{|c|}{ Delivery of mothers in health facilities } \\
\hline No & 1 & 0.26 \\
\hline Yes & 383 & 99.74 \\
\hline \multicolumn{3}{|c|}{ Early initiation of breastfeeding } \\
\hline No & 30 & 7.81 \\
\hline Yes & 354 & 92.19 \\
\hline \multicolumn{3}{|c|}{ Colostrum administration } \\
\hline No & 15 & 3.91 \\
\hline Yes & 369 & 96.09 \\
\hline \multicolumn{3}{|c|}{ Exclusive breastfeeding } \\
\hline No & 27 & 7.03 \\
\hline Yes & 357 & 92.22 \\
\hline \multicolumn{3}{|c|}{ Provision of complementary foods for infant over 6 months } \\
\hline No & 3 & 0.78 \\
\hline Yes & 381 & 99.22 \\
\hline \multicolumn{3}{|c|}{ Giving Vitamin A twice to children under 2 years of age } \\
\hline No & 1 & 0.26 \\
\hline Yes & 383 & 99.74 \\
\hline \multicolumn{3}{|c|}{ Giving Vitamin A to postpartum mothers } \\
\hline No & 7 & 1.82 \\
\hline Yes & 377 & 98.18 \\
\hline \multicolumn{3}{|c|}{ Complete basic immunization } \\
\hline No & 5 & 1.30 \\
\hline Yes & 379 & 98.70 \\
\hline \multicolumn{3}{|c|}{ Regular visits to Posyandu (integrated service posts) } \\
\hline No & 2 & 0.52 \\
\hline Yes & 382 & 99.48 \\
\hline
\end{tabular}

above the respective $\mathrm{WHO} 0 \mathrm{Z}$ scores continue to grow adequately and at 18 and 24 months have length and weight above the WHO $0 \mathrm{Z}$ scores [20]. It was found that breastfeeding has a significant relationship with stunting and severe stunting in the $2^{\text {nd }}$ and $3^{\text {rd }}$ years of life. To reduce the burden of undernutrition in the country, mothers need to be informed about the risks of prolonged breastfeeding [21]. The Ipa study shows that children refuse to breastfeed (10\%), have $17.3 \%$ formula milk, the reason kids do not breastfeed over 2 years. For the prevention of stunting, breastfeeding frequency was significant [22]. All breastfeeding and being female were consistent protective variables across all models against child stunting. Stunting models can be achieved by maximizing better breastfeeding [23], [24]. To avoid bottle feeding, infant and child feeding is carried out to the extent possible. A good understanding of cleanliness and presentation is required when forced to use a milk bottle [25].

Optimal growth and development in early childhood is determined by a complex interplay of child, maternal, household, environmental, and socioeconomic factors influencing nutritional intake, but interventions to decrease child malnutrition sometimes target specific risk factors in isolation [26], [27], [28]. The SUN Movement in Indonesia is called the National Movement for the Acceleration of Improvement of Nutrition in the First 1000 Days of Life Framework, shortened to the First 1000 Days of Life Movement. A series of activities have been carried out to formulate the first 1000 days of life movement in Indonesia, involving key stakeholders consisting of ministries and institutions, the business world, international development partners, social and community organizations, and supported by ministries and institutions. The first 1000 days of life movement consists of specific nutrition interventions and sensitive nutrition interventions. The Government of the Republic of Indonesia launched the National Strategy for Accelerating Stunting Prevention 20182024 with priority targets which are pregnant women and children aged $0-2$ years or the first 1000 days of life. The interventions were in the form of specific and sensitive nutrition interventions [29].

Specific nutritional interventions include supplementary feeding for pregnant women who experience chronic energy deficiency, provision of supplemented blood tablets to pregnant women, consumption of iodized salt, exclusive breastfeeding, breastfeeding until the age of 2 years accompanied by breast milk adequate, and children under 2 immunization status [30]. Research conducted by Rosha et al. on the role of specific and sensitive nutrition interventions in improving nutritional problems in Bogor City states that specific nutrition interventions include maternal intervention (pregnant women class, supplementary feeding for pregnant women, nutrition, and health seminars) and toddler intervention (monitoring toddlers in Posyandu, immunization, vitamins, and supplementary feeding and youth intervention) [31]. Muthia's (2019) research on the Evaluation of the Implementation of the Stunting Prevention Program in terms of the Specific Nutrition Intervention of the First 1000 Days of life Movement at Pegang Baru community health center Pasaman Regency stated that preventing stunting through specific intervention programs had not reduced stunting below $20 \%$ [32].

Systematic reviews of 14 studies in low- and middle-income countries show that the education of mothers and their partners is the most significant factor influencing maternal health service use in addition to wealth quintile, media exposure, and rural/urban housing [33]. There are five factors that contribute to stunting, namely, household and family factors, inadequate complementary feeding, inadequate breastfeeding practices, infectious disease factors, and social and community factors. Household and family factors include malnutrition during pre-conception, pregnancy and breastfeeding, short mothers, infections, teenage pregnancy, mental health, intrauterine growth retard and preterm birth, close labor distance, hypertension, stimulation and activity inadequate children, poor care practices, inadequate sanitation and water supply, food insecurity, inadequate household food allocation, and low caregiver education. Inadequate complementary food factors include poor quality micronutrients in complementary foods, low food diversity and food ingredients containing anti-nutrition, low-energy content in complementary foods, rarely, inadequate food during 
Table 3: Specific interventions and nutritional status children under $\mathbf{2}$ children under 2 years after the natural disaster

\begin{tabular}{|c|c|c|c|c|c|}
\hline \multirow[t]{3}{*}{ Variable } & \multicolumn{4}{|c|}{ Nutritional status children under 2} & \multirow[t]{3}{*}{$\mathrm{p}$-value } \\
\hline & \multicolumn{2}{|l|}{ Stunting } & \multicolumn{2}{|l|}{ Normal } & \\
\hline & $n=143$ & $(\%)$ & $n=241$ & $(\%)$ & \\
\hline \multicolumn{6}{|c|}{ Children age (month) } \\
\hline $0-11$ & 47 & 24.23 & 147 & 75.77 & \multirow[t]{2}{*}{$0.000^{*}$} \\
\hline $12-23$ & 96 & 50.53 & 94 & 49.47 & \\
\hline \multicolumn{6}{|c|}{ Breastfeeding until 2 years of age } \\
\hline No & 9 & 21.43 & 33 & 78.57 & \multirow[t]{2}{*}{$0.025^{*}$} \\
\hline Yes & 134 & 39.18 & 208 & 60.82 & \\
\hline \multicolumn{6}{|c|}{ Giving biscuit to pregnant women } \\
\hline No & 7 & 38.89 & 11 & 61.11 & \multirow[t]{2}{*}{0.882} \\
\hline Yes & 136 & 37.16 & 230 & 62.84 & \\
\hline \multicolumn{6}{|c|}{ Provision of iron supplement tablets to pregnant women } \\
\hline No & 0 & 0 & 1 & 100 & \multirow[t]{2}{*}{0.441} \\
\hline Yes & 143 & 37.47 & 240 & 62.66 & \\
\hline \multicolumn{6}{|c|}{ Calcium supplementation to pregnant women } \\
\hline No & 1 & 20.0 & 4 & 80.00 & \multirow[t]{2}{*}{0.422} \\
\hline Yes & 142 & 37.47 & 237 & 62.53 & \\
\hline \multicolumn{6}{|c|}{ Delivery of mothers in health facilities } \\
\hline No & 0 & 0 & 1 & 100 & \multirow[t]{2}{*}{0.441} \\
\hline Yes & 143 & 37.24 & 240 & 62.66 & \\
\hline \multicolumn{6}{|c|}{ Early initiation of breastfeeding } \\
\hline No & 9 & 30.00 & 21 & 70.0 & \multirow[t]{2}{*}{0.393} \\
\hline Yes & 134 & 37.85 & 220 & 62.15 & \\
\hline \multicolumn{6}{|c|}{ Colostrum administration } \\
\hline No & 2 & 13.33 & 13 & 86.67 & \multirow[t]{2}{*}{0.051} \\
\hline Yes & 141 & 38.21 & 228 & 61.79 & \\
\hline \multicolumn{6}{|c|}{ Exclusive breastfeeding } \\
\hline No & 6 & 22.22 & 21 & 77.78 & \multirow[t]{2}{*}{0.094} \\
\hline Yes & 137 & 38.38 & 220 & 61.62 & \\
\hline \multicolumn{6}{|c|}{ Provision of complementary foods for infant over 6 months } \\
\hline No & 0 & 0 & 3 & 100 & 0.180 \\
\hline Yes & 143 & 37.24 & 238 & 62.47 & \\
\hline Giving Vit & & & & & \\
\hline No & 0 & 0 & 1 & 100 & 0.441 \\
\hline Yes & 143 & 37.24 & 240 & 62.66 & \\
\hline Giving Vit & & & & & \\
\hline No & 2 & 28.57 & 5 & 71.43 & 0.632 \\
\hline Yes & 141 & 37.40 & 236 & 62.60 & \\
\hline Complete & & & & & \\
\hline No & 3 & 60.0 & 2 & 40.0 & 0.289 \\
\hline Yes & 140 & 36.94 & 239 & 63.06 & \\
\hline Regular v & & & & & \\
\hline No & 1 & 50.0 & 1 & 50.0 & 0.708 \\
\hline Yes & 142 & 37.17 & 240 & 62.83 & \\
\hline
\end{tabular}

and after illness, consistency of liquid food, insufficient amount of food, food unresponsiveness, contamination of food and water, poor hygiene practices, unsafe storage, and preparation [34].

Consistent evidence of the Indonesian stunting determinant shows that non-exclusive breastfeeding, low household socioeconomic status, preterm birth, short birth length, low maternal height, and education for the first 6 months are the determinants of stunting in Indonesia. There are also greater risks for households with latrines that are not repaired and untreated drinking water. Community factors, poor access to health care and rural living, have been linked repeatedly to stunting [35]. The significant proximal drivers were improvements in early initiation of breastfeeding and a decrease in the prevalence of low birth weight. The findings reinforce the need to address the problem of stunting with a combination of nutrition-sensitive and specific interventions. The identified drivers help guide global efforts to further speed up the reduction of stunting and monitor progress against chronic undernutrition in children [36], [37], [38]. In their role in nutritional food choices, variables such as social, cultural, environmental, economic, gender, knowledge, and information intersect [39]. Data remain sparse on the coverage of many specific and sensitive nutritional interventions. The most often accessed country-specific data source was the Demographic Health Surveys and Global Nutrition Report [40].

\section{Conclusions}

Children breastfeeding up to 2 years are specified interventions to prevent stunting in children under 2 years after natural disasters. About $37.24 \%$ is the prevalence of stunting in children under 2 . To reduce stunting problems in the Indonesian town of Palu Central Sulawesi, mothers need to be informed about the risks and local and central government assistance.

\section{Acknowledgments}

We would like to express our gratitude to the Head of the Health Development and Empowerment Agency for Human Resources of the Republic of Indonesia, to the Director of Palu Health Polytechnic, to all the participants in the research and enumerator research.

\section{References}

1. Fanzo J. The Biology of the First 1,000 Days. In: Karakochuk CD, Whitfield KC, Green TJ, Kraemer K, editors. The Biology of the First 1,000 Days. Boca Ratorl. Taytor and Frantcis, 2018. 
Boca Raton, Florida: CRC Press; 2017. p. 389-408. https://doi. org/10.1201/9781315152950

2. Islam MS, Ullah AN, Mainali S, Imam MA, Hasan MI. Determinants of stunting during the first 1,000 days of life in Bangladesh: A review. Food Sci Nutr. 2020;8(9):4685-95. https://doi.org/10.1002/fsn3.1795

3. Black RE, Heidkamp R. Causes of stunting and preventive dietary interventions in pregnancy and early childhood. In: Nestle Nutrition Institute Workshop Series. Dubai: KARGER 2017. p. 105-13. https://doi.org/10.1159/000486496

4. Ministry of National Development Planning of the Republic of Indonesia. Pedoman Perencanaan Program Gerakan Nasional Percepatan Perbaikan Gizi Dalam Rangka Seribu Hari Pertama Kehidupan (Gerakan 1000 HPK). Jakarta: Ministry of National Development Planning of the Republic of Indonesia; 2013. https://doi.org/10.18311/jeoh/2020/26134

5. Kementerian Kesehatan. Riset Kesehatan Dasar. Vol. 2014 Jakarta: Kementerian Kesehatan; 2013. Available from: http:// www.depkes.go.id/downloads/riskesdas2013/Hasil Riskesdas 2013.pdf. https://doi.org/10.24252/bio.v5i1.3429 [Last accessed on 2020 Dec 12]

6. Kementerian Kesehatan RI. Hasil Utama Riskesdas 2018. Jakarta: Ministry of Health (Kementerian Kesehatan Republik Indonesia); 2018. Available from: http://www.depkes.go.id/ resources/download/info-terkini/materi_rakorpop_2018/ Hasil Riskesdas 2018.pdf. https://doi.org/10.22435/kespro. v10i2.2568. [Last accessed on 2020 Dec 10]

7. Angood C, Khara T, Dolan C, Berkley JA, WaSt Technical Interest Group. Research priorities on the relationship between wasting and stunting. PLoS One. 2016;11(5):e0153221. https:// doi.org/10.1371/journal.pone.0153221

PMid:27159235

8. Sumiaty, Pont AV, Sundari S. Relationship of mother factors, breastfeeding and stunting pattern in Central Sulawesi. Int J Sci Basic Appl Res. 2017;35(3):413-20.

9. Agedew E, Chane T. Prevalence of stunting among children aged 6-23 months in Kemba Woreda, Southern Ethiopia: A community based cross-sectional study. Adv Public Heal. 2015;2015:164670. https://doi.org/10.4172/2155-9600.1000381

10. Aguayo VM, Badgaiyan N, Paintal K. Determinants of child stunting in the $R$ oyal $K$ ingdom of $B$ hutan: An in-depth analysis of nationally representative data. Matern Child Nutr. 2015;11(3):333-45. https://doi.org/10.1111/mcn.12168 PMid:25536283

11. Nasrul. Pengendalian Faktor Risiko Stunting Anak Baduta di Sulawesi Tengah. Promot J Kesehat Masy. 2018;8(2):131-46. https://doi.org/10.31934/promotif.v8i2.495

12. Susiloretni KA, Hadi $H$, Blakstad MM, Smith ER, Shankar AH. Does exclusive breastfeeding relate to the longer duration of breastfeeding? A prospective cohort study. Midwifery. 2019;69:163-71. https://doi.org/10.1016/j.midw.2018.11.008 PMid:30522038

13. Direktur Anggaran Bidang Pembangunan Manusia dan Kebudayaan Kementerian Keuangan. Penanganan Stunting Terpadu Tahun 2018. Jakarta: Direktur Anggaran Bidang Pembangunan Manusia dan Kebudayaan Kementerian Keuangan; 2018. https://doi.org/10.33827/akurasi2017.vol1. iss2.art24

14. Sassa S, Takagawa T. Liquefied gravity flow-induced tsunami: First evidence and comparison from the 2018 Indonesia Sulawesi earthquake and tsunami disasters. Landslides. 2019;16(1):195200. https://doi.org/10.1007/s10346-018-1114-x

15. Carvajal M, Araya-Cornejo C, Sepúlveda I, Melnick D, Haase JS. Nearly instantaneous tsunamis following the mw 7.52018 palu earthquake. Geophys Res Lett. 2019;46(10):5117-26. https:// doi.org/10.1029/2019gl082578
16. Sahadewa A. Overview of the 2018 palu earthquake. In: Earthquake Geotechnical Engineering for Protection and Development of Environment and Constructions Proceedings of the 7th International Conference on Earthquake Geotechnical Engineering; 2019. p. 857-69. https://doi. org/10.1201/9780429031274

17. Mokhtari R. Assessing and comparing nutritional status and related factors among 6-48 months old children born in the damaged rural and urban areas of Varzeghan after the 2012 earthquake. Prog Nutr. 2019;21:107-12.

18. Thorne-Lyman AL, Manohar S, Shrestha B, Nonyane BA, Neupane $\mathrm{S}$, et al. Nutritional resilience in Nepal following the earthquake of 2015. PLoS One. 2018;13(11):e0205438. https:// doi.org/10.1371/journal.pone.0205438 PMid:30403683

19. Moghadam MN, Amiresmaieli M, Hassibi M, Doostan F, Khosravi S. Toward a better nutritional aiding in disasters: Relying on lessons learned during the bam earthquake. Prehosp Disaster Med. 2017;32(4):382-6. https://doi.org/10.1017/ s1049023x17006355 PMid:28345496

20. Haschke F, Binder C, Huber-Dangl M, Haiden N. Early life nutrition, growth trajectories, and long-term outcome. In: Nestle Nutrition Institute Workshop Series. Nestlé Nutrition Institute Workshop Series; 2019. p. 107-20. https://doi. org/10.1159/000490299

21. Syeda B, Agho K, Wilson L, Maheshwari GK, Raza MQ. Relationship between breastfeeding duration and undernutrition conditions among children aged 0-3 Years in Pakistan. Int $\mathrm{J}$ Pediatr Adolesc Med. 2020;2020:1-6. https://doi.org/10.1016/j. ijpam.2020.01.006

22. Ipa A, Hartono R, Sirajuddin, Amir A, Ishak SI. Breast feeding practice prevention for nutritional stunting of children in Buginese ethnicity. Indian J Forensic Med Toxicol. 2020;14(3):1108-12.

23. Bustami B, Ampera $M$. The identification of modeling causes of stunting children aged 2-5 years in Aceh Province, Indonesia (data analysis of nutritional status monitoring 2015). Open Access Maced J Med Sci. 2020;8(E):657-63. https://doi. org/10.3889/oamjms.2020.4659

24. Campos AP, Vilar-Compte M, Hawkins SS. Association between breastfeeding and child stunting in Mexico. Ann Glob Health. 2020;86(1):145. https://doi.org/10.5334/aogh.2836 PMid:33262934

25. Nasrul N, Hafid F, Ramadhan K, Suza DE, Efendi F. Factors associated with bottle feeding in children aged 0-23 months in Indonesia. Child Youth Serv Rev. 2020;116:105251. https://doi. org/10.1016/j.childyouth.2020.105251

26. Kim R, Mejía-Guevara I, Corsi DJ, Aguayo VM, Subramanian S V. Relative importance of 13 correlates of child stunting in South Asia: Insights from nationally representative data from Afghanistan, Bangladesh, India, Nepal, and Pakistan. Soc Sci Med. 2017;187:144-54. https://doi.org/10.1016/j. socscimed.2017.06.017 PMid:28686964

27. Corsi DJ, Mejía-Guevara I, Subramanian SV. Risk factors for chronic undernutrition among children in India: Estimating relative importance, population attributable risk and fractions. Soc Sci Med. 2016;157:165-85. https://doi.org/10.1016/j. socscimed.2015.11.014

PMid:26625852

28. Mbwana HA, Kinabo J, Lambert C, Biesalski HK. Factors influencing stunting among children in rural Tanzania: An agroclimatic zone perspective. Food Secur. 2017;9(6): 1157-1171. https://doi.org/10.1007/s12571-017-0672-4

29. Satriawan E. Strategi Nasional Percepatan Pencegahan Stunting 2018-2024 (National Strategy for Accelerating Stunting 
Prevention 2018-2024); 2018. p. 1-32.

30. Ministry of Health. The Stategy and policy to involve property in Indonesia. Germas. 2019;2(2):41-52.

31. Rosha BC, Sari K, Yunita SP, Amaliah N, Utami NH. Peran intervensi gizi spesifik dan sensitif dalam perbaikan masalah gizi balita di kota Bogor. Bul Penelit Kesehat. 2016;44(2):127-38. https://doi.org/10.22435/bpk.v44i2.5456.127-138

32. Muthia G. Evaluasi Pelaksanaan Program Pencegahan Stunting Ditinjau Dari Intervensi Gizi Spesifik Gerakan 1000 HPK di Puskesmas Pegang Baru Kabupaten Pasaman. Andalas: e-Skripsi Universitas Andalas; 2019. https://doi.org/10.25077/ jka.v8i4.1125

33. Banke-Thomas $\mathrm{O}$, Banke-Thomas $\mathrm{A}$, Ameh CA. Utilisation of maternal health services by adolescent mothers in Kenya: Analysis of the demographic health survey 2008-2009. Int J Adolesc Med Health. 2018;30(2):1-42. https://doi.org/10.1515/ ijamh-2016-0042 PMid:27732558

34. Stewart CP, lannotti L, Dewey KG, Michaelsen KF, Onyango AW. Contextualising complementary feeding in a broader framework for stunting prevention. Matern Child Nutr. 2013;9(S2):27-45. https://doi.org/10.1111/mcn.12088

PMid:24074316

35. Beal T, Tumilowicz A, Sutrisna A, Izwardy D, Neufeld LM. A review of child stunting determinants in Indonesia. Matern Child Nutr. 2018;14(4):e12617. https://doi.org/10.1111/mcn.12617 PMid:29770565
36. Kim R, Rajpal S, Joe W, Corsi DJ, Sankar R, Kumar A, et al. Assessing associational strength of 23 correlates of child anthropometric failure: An econometric analysis of the 2015-2016 national family health survey, India. Soc Sci Med. 2019;238:112374. https://doi.org/10.1016/j. socscimed.2019.112374

37. Darsene H, Geleto A, Gebeyehu A, Meseret S. Magnitude and predictors of undernutrition among children aged six to fifty nine months in Ethiopia: A cross sectional study. Arch Public Health. 2017;75:29. https://doi.org/10.1186/s13690-017-0198-4

38. Argaw A, Hanley-Cook G, De Cock N, Kolsteren P, Huybregts L, Lachat $\mathrm{C}$. Drivers of under-five stunting trend in 14 low- and middle-income countries since the turn of the millennium: A multilevel pooled analysis of 50 demographic and health surveys. Nutrients. 2019;11(10):2485. https://doi.org/10.3390/ nu11102485

PMid:31623183

39. Lusambili A, Naanyu V, Manda G, Mossman L, Wisofschi S, Pell R, et al. Nutritional influences on the health of women and children in cabo delgado, mozambique: A qualitative study. Int J Environ Res Public Health. 2020;17(17):6205. https://doi. org/10.3390/ijerph17176205 PMid:32867019

40. Buckland AJ, Thorne-Lyman AL, Aung T, King SE, Manorat R, Becker $L$, et al. Nutrition data use and needs: Findings from an online survey of global nutrition stakeholders. J Glob Health. 2020;10(2):20403. https://doi.org/10.7189/jogh.10.020403 PMid:33282221 